\title{
Refugee Integration and Globalization: Ugandan and Zimbabwean Perspectives
}

\author{
Charles Kiiza Wamara' ${ }^{1} \cdot$ Munyaradzi Muchacha $^{2} \cdot$ Benard Ogwok $^{3} \cdot$ Cornelius Dudzai $^{2}$
}

Accepted: 1 June 2021 / Published online: 25 September 2021

(c) The Author(s) 2021

\begin{abstract}
This article examines refugee integration in a globalizing world through the example of the efforts made, and challenges faced, by refugees, communities, and governments in Zimbabwe and Uganda. Using documentary analysis, the article shows how the two countries have striven to integrate refugees through encampment and non-camp settlement policies despite structural challenges such as restrictions on movement, economic crises, high unemployment, and limited state funding and resources. The article begins by conceptualizing globalization and integration and then reviews the perspectives on refugee integration in the two countries. It concludes with some recommendations to improve refugee integration in both countries.
\end{abstract}

Keywords Integration $\cdot$ Refugees $\cdot$ Globalization $\cdot$ Zimbabwe $\cdot$ Uganda

\section{Introduction}

The global interconnection of most spheres of human lifeculture, politics, economy, technology, and education-is facilitated by, and facilitates, the great tides of international migration (Castles \& Miller, 2003; Castles et al., 2002; Jones, 2006) that have "become a reality that touches nearly all corners of the globe" (UN, 2015, p. 1). The United Nations High Commissioner for Refugees (UNHCR, 2020a) reported 79.5 million forcibly displaced people, 26 million of whom were refugees. With peace deteriorating in Ethiopia, Eritrea, Armenia, Azerbaijan, Syria, Afghanistan, South Sudan, Somalia, and elsewhere, even more people will be

Charles Kiiza Wamara

wamaracharles@gmail.com; charles.kiiza-wamara@oru.se

Munyaradzi Muchacha

munyaradzimuchacha@gmail.com

Benard Ogwok

ogwokbenard2016@gmail.com

Cornelius Dudzai

corneliusdudzai9@gmail.com

1 School of Law, Psychology and Social Work, Örebro University, S-70182 Örebro, Sweden

2 Department of Social Work, University of Zimbabwe, Mt Pleasant, P.O. Box MP 167, Harare, Zimbabwe

3 School of Health and Social Care, University of Lincoln, Brayford Pool, Lincoln LN67TS, Lincolnshire, UK displaced, further stressing the complex and gradual process of local integration that, despite globalization's facilitation, imposes legal, economic, social, and cultural demands on both the individual and the receiving society (Castles \& Miller, 2003).

Traditionally concerned with protecting the rights and entitlements of their citizens (Hugman et al., 2010), countries faced with increasing globalization and forced migration now focus more on integrating the new immigrants (Karakayali \& Rigo, 2010). This shift has been accelerated by worsening refugee crises in both the Global North and the South that oblige countries to accept and provide for ever more people. Such countries' practices, policies, and procedures are now influenced by the broader processes and realities of globalization (Bauman, 1998). The UN (2000) contends that countries able to ride the wave of globalization respond to increased migration with an appreciation of global citizenship, comfort with uncertainty, and optimism about the future, and can then open their policy analyses to uncertainty, ambiguity, and change. Countries previously hostile toward immigrants have begun to change (Polzer, 2008), and recent evidence shows many adopting integrative and transformative approaches to managing emerging aspects of globalization (Kreibaum, 2016).

International migration includes many different types of migrants, most of whom have moved to countries in the Global South. Academic discussions on refugee integration, however, have mainly discussed the issue in terms of the 
Global North. To redress this imbalance and contribute to a more global perspective, this article focuses on progress and challenges in integrating refugees in the seldom studied African countries of Uganda and Zimbabwe and refugees.

\section{Conceptualizing Globalization and Refugee Integration}

Conceptualizing, defining, and interpreting globalization is a complex task due to the many contexts and fields in which this word is variously applied (Jones, 2006). Globalization is not a static concept, but a quickly evolving (Jones, 2006) and highly contested domain, with no clear lines of demarcation (Mittelman, 2004). Hundreds of definitions exist for globalization, and interpretation largely depends on the theoretical lens or perspective. Despite the many conflicting interpretations, however, most definitions agree that globalization is driven by the international movement of people, goods, capital, ideas, and values across the globe. As Angell noted as early as 1911:

The world economy has become as highly interdependent as to make national independence an anachronism, especially in financial markets. The interdependence is driven by science, technology and economics - the forces of modernity; and these forces, not governments, determined international relations. (p. 17)

His observation makes sense, especially considering Harvey's (2005) assertion that globalization emerged mostly in the realm of economic gain, of which the "neoliberalist blitz" conveniently takes advantage.

Albrow (1990), however, views globalization not only as economic, but also as involving all those processes by which the peoples of the world are incorporated into a single world society, global society, culture, and web of social relations. Appadurai (1990) adds that, from a cultural perspective, "what is taking place is a process of cultural mixing or hybridization across locations and identities" (p. 90). From a political perspective, Beck (2000) notes that globalization implies the weakening of state sovereignty and state structures. Beerkens (2004) looks beyond the demise of state sovereignty and argues that with globalization "social arrangements (like power, culture, markets, politics, rights, values, norms, ideology, identity, citizenship and solidarity) become disembodied from their spatial context" (p. 9). A popular definition in sociology comes from Giddens (1990), who maintained that globalization is "the intensification of worldwide social relations which link distant localities in such a way that local happenings are shaped by events occurring many miles away and vice versa" (p. 64). From these definitions, we can surmise that globalization is saliently international, aggressive, multi-dimensional, systematic, dynamic, complex, and irreversible (Beck, 2000; Beerkens, 2004).

Various theories have emerged, especially from sociology and anthropology, to explain globalization. Held et al. (1999) identified three strands of theoretical perspectives on globalization: hyperglobalism, transformationalism, and skepticism. A hyperglobalist perspective offers an overly optimistic analysis, arguing that globalization is a legitimate, socially desirable, and progressive process, with great economic, cultural, social, and political gains that outweigh any negative consequences (Fukuyama, 1992). Skeptics, however, argue that individual states still wield a great deal of influence and globalization is slowing, its golden age back in the nineteenth century. Skeptics also view globalization as post-colonial imperialism and imperialist cultural expansionism, and they question most arguments of the hyperglobalists (Cambridge, 2000). Transformationalists depart from hyperglobalists and skeptics to view globalization as a multi-layered, non-linear, progressive, and transformative process. Held et al., (2000) hold its powerful transformative force responsible for a massive shakeout of societies, economies, institutions of governance, and the world order. Another transformationalist, Giddens (2001), maintains that globalization is the spread of four forces of Western modernity: the world capitalist economy, the nation-state system, the world military order, and the international division of labor.

The tide of globalization has facilitated great movements not only of goods and capital, but also of people (Castles \& Van Hear, 2005; Castles et al., 2002). The UN (2015) estimated cross-national migration would likely continue to increase due to economic opportunity, poverty, climate change, war, and instability. As people move to different places, they are compelled to integrate into various, often new, social and economic spheres such as the labor market, local culture, and new social relations (Castles, 2004; Castles \& Van Hear, 2005). Integrating refugees and migrants has therefore become a topical and highly challenging issue (Castles \& Miller, 2003) affecting and affected by history, tradition, economics, human rights, national policy, and national identity all over the world.

Like other social issues, integration is challenging to define and conceptualize because it has so many faces. As Robinson (1998) observes, "meanings of integration vary from country to country, change over time, and depend on the interests, values and perspectives of the people concerned; integration is individualized, contested and contextual" (p. 118). Sigona (2005) concurs that integration is a complex process involving "many actors, agencies, logics and rationalities" (p. 118), and so it is often used interchangeably with other terms such as assimilation, adoption, adaptation, and accommodation. Penninx (2004) conceptualizes integration holistically under four major 
categories: cultural, social, economic, and political. Cultural integration pertains to learning and adopting new cultural knowledge such as language (Castles et al., 2002); social integration concerns local social relations and services such as health and education (Castles \& Miller, 2003); political integration is participation in political processes such as voting (Castles et al., 2002); and economic integration refers to participating in the economy, though the labor market or business, for example (Castles \& Miller, 2003). Like Penninx (2004), Crisp (2004) provides a comprehensive and three-dimensional definition of integration:

Firstly, it is a legal process, whereby refugees attain a wider range of rights in the host state. Secondly, it is an economic process of establishing sustainable livelihoods and a standard of living comparable to the host community. Thirdly, it is a social and cultural process of adaptation and acceptance that enables the refugees to contribute to the social life of the host country and live without fear of discrimination. (p. 1)

However, as this paper demonstrates, integration in Uganda and Zimbabwe falls short of most of this definition, confirming the complexity of the process.

\section{Methodology}

The article relies on documentary analysis to describe refugee integration in the two African countries (Stake, 1995). We analyzed both technical and non-technical documents because scientific studies on refugee integration in these countries are limited. The technical documents included scientific journals, books, theses, conference papers, and working papers. The non-technical documents consisted of institutional reports and press releases. Documents were selected for analysis through an exhaustive search of the internet and databases such as the Sociology Collection, the Social Science Premium Collection, and Sociological Abstracts. We mainly used phrase and free text searches because some terms needed to be searched consecutively. The concepts of refugee integration, refugee support, refugee responses, and refugee challenges were used to identify the documents.

The scope of the analysis did not permit us to review documents about refugee integration in countries other than Uganda and Zimbabwe. These two countries were chosen not only because most academic discussions focus on refugee integration in the Global North, but also because these are the authors' home countries. Given the scarcity of relevant documentation, we limited inclusion criteria to relevancy and publication in English. Date of publication, while perhaps of interest, was not ground for inclusion. Of the 56 documents identified in the search, many were irrelevant and did not address the integration of refugees. The final sample for analysis comprised 14 documents ( 3 scientific and 11 non-scientific) addressing the phenomenon of refugee integration.

\section{Integration of Refugees in Zimbabwe}

Because of political instability, many people continue to flee sub-Saharan Africa, some seeking refuge in Zimbabwe. In 2014, Zimbabwe hosted about 9493 refugees and asylum seekers (Mhlanga \& Zengeya, 2016), mostly from Burundi, the Democratic Republic of Congo (DRC), Eritrea, Mozambique, Rwanda, and to some extent Ethiopia (UNHCR, 2014). About $97 \%$ of the refugees at Tongogara Refugee Camp in Zimbabwe were from the Great Lakes region countries (Burundi 7\%, DRC 80\%, and Rwanda 10\%); the remaining 3\% were mainly from the Horn of Africa: Eritrea, Ethiopia, and Somalia (UNHCR, 2014). As of October 2020, the number of refugees at Tongogara Refugee Camp in Zimbabwe stood at 10,563 (UNHCR, 2020b). Encouragingly, most of these people have successfully applied for refugee status, and Zimbabwe has been praised by the UNHCR for awarding refugee status to most asylum seekers (Chikanda \& Crush, 2016), enabled by its Refugee Act of 1983, which facilitates the speedy and fair legalization and settlement of refugees (Klaaren \& Rutinwa, 2004).

Zimbabwe mostly pursues a policy of refugee encampment, confining refugee settlement to camps (Chikanda $\&$ Crush, 2016). The encampment policy is guided by the Refugee Act of 2001 (Republic of Zimbabwe, 2001). Under this policy, refugees are restricted to the camps, where (in line with Article 33 of the 1951 UN Convention) they are protected from expulsion or return to dangerous or wartorn countries. In the camp, social workers strive to provide psychosocial support and adjustment services to unaccompanied minors, people with physical hand and mental challenges, the elderly, single women, and the terminally ill (Mhlanga \& Zengeya, 2016). Social workers also link refugees with resources and systems that can help to fill their various needs. Different state and non-state actors also assist through providing items such as maize, grain, cooking oil, and clothes.

The encampment policy pursued in Zimbabwe limits the movement of refugees across the country, is a barrier to their integration in society and local communities, and is a form of repression that may violate Article 13 (1) of the Universal Declaration of Human Rights (UDHR), entitling all people to freedom of movement. Under the policy, most refugees cannot move to pursue a livelihood through work or business as their designated residence is the camp (Chikanda \& Crush, 2016), which violates Article 23 (1) of the UDHR on people's right to work and freedom of employment. Through denying refugees these important rights, the Zimbabwean encampment policy also denies them social, cultural, and 
economic integration, which in turn preclude their political integration (Chikanda \& Crush, 2016). The exclusion of refugees from these vital arenas is arguably yet another violation of the UDHR, in this case Article 27 (1), which states that everyone has the right to participate freely in the cultural life of the community, to enjoy the arts, and to share in scientific advancement and its benefits.

To obey international law, some African countries such as South Africa and Botswana have abolished encampment policies and permitted those with refugee status to enjoy freedom of movement and the pursuit of various livelihoods (UNHCR, 2015). In Zimbabwe, however, only wealthy refugees have been allowed to move away from the camp to other areas, perhaps because the state wants those refugees to invest in local economies. Another reason could be that the state wants to deny responsibility for these refugees, who presumably can provide for themselves. However, very few refugees can actually move away. Because of the conditions in the refugee camp and the rarity of anyone being allowed to leave, the meaningful economic, social, and cultural integration of refugees in Zimbabwe seems unlikely except for a lucky few (Chikanda \& Crush, 2016). However, people are resourceful, and about $25 \%$ of refugees in Uganda, in contrast, have earned livelihoods in refugee camps through various methods such as farming, vending, and operating barber shops and small stores to supplement the support they receive from international organizations (UNHCR, 2015). These livelihoods, however, are precarious and lacking in financial capital, state support, electricity, demand for their goods and services, and spendable income among prospective client/customer refugees (Klaaren \& Rutinwa, 2004).

\section{Integration of Refugees in Uganda}

Uganda has been a welcoming nation since and because of its formation by over 56 tribes such as the Nilotic, NiloHamite, and Hamite peoples that migrated to Uganda from other parts of Africa (Chigwedere, 1998). To attest to its tradition of hospitality, Uganda hosted 7000 Polish refugees after World War II (Sharpe \& Namusobya, 2012). Since then, it has continued to receive frequent refugees from DRC, Eritrea, Ethiopia, Kenya, Nigeria, Pakistan, Rwanda, Somalia, South Sudan, and Sudan. Between 2016 and 2017, the country received a record-breaking refugee population of 1.4 million, making Uganda the second highest refugeehosting country in the world after Turkey (UNHCR, 2018). Official statistics estimated the daily influx of refugees at about 2000 (Office of the Prime Minister, 2017). By the end of January 2020, the country still hosted 1,394,678 refugees. Of these, the highest population $(867,453)$, came from South Sudan, while 46,707, 402,521, and 77,997 refugees respectively came from Burundi, DRC, and a mix of other countries (UNHCR, 2020c). This influx has continued to increase as unresolved political questions cause more chronic and exacerbated instability in Burundi, DRC, Somalia, and South Sudan. Refugees in Uganda settle mainly in the West Nile districts of Adjumani, Arua, Moyo, Koboko, and Yumbe, which host 752,596 refugees, while the western districts of Hoima, Isingiro, Kamwenge, Kiryandongo, and Kyegegwa have 508,017 refugees, and in northern Uganda, Lamwo has the highest population of 52,547 (UNHCR, 2020c). Many "self-settled refugees," however, live outside the refugee settlement areas, and other "urban refugees" have settled in cities and towns, including 78,501 in and around Kampala (UNHCR, 2020c). Self-settled and urban refugees control their own lives and receive no material support from government or refugee assistance organizations. There are no official refugee counts, however, partly because the relevant information system, database, and documentation are poorly managed and partly because Uganda's permeable borders allow refugees to enter and settle extra-legally, sometimes with Ugandan relatives.

Most significantly, Uganda is a signatory to the 1951 Refugee Convention, the 1967 Protocol Relating to the Status of Refugees, and the Organization of African Unity Convention Governing the Specific Aspects of Refugee Problems in Africa. To fulfill its commitments to these international and regional conventions, the country enacted the Refugee Act in 2006 to protect the rights of the refugees. This law replaces the Control of Alien Refugees Act of 1960, which focused more on controlling "unwanted aliens" than protecting refugees (Lomo et al., 2001). Crucially, the Refugee Act recognizes significant international and regional conventions including refugee protection and their rights to an identity card, non-discrimination, elementary education, gainful employment, freedom of movement, freedom of religion, and legal assistance (Refugee Act 2006, Sects. 29-36). Opinion leaders have commended this law as progressive and oriented to protecting human rights (Refugee Law Project, 2009). Better still, since 2017 the country has developed important documents such as the Uganda Comprehensive Refugee Response Framework to protect refugees and facilitate refugee integration through supporting local hosting districts to empower refugees to be self-reliant.

In contrast to Zimbabwe and other countries, Uganda pursues a non-camp policy to create local refugee settlements. Under this policy, refugees are allocated relatively large plots $(100 \times 100$ feet $[\sim 30.5 \times 30.5 \mathrm{~m}])$ of land to farm, produce their own food, and sell the surplus. The size of the plot, however, depends on the number of refugees in each location. The government also provides non-food items, materials to build a basic home, food aid until crops mature, a health center, and a primary, a secondary, and a vocational training school in each location (Omata \& Kaplan, 2013; UNHCR, 2003). These settlements differ from camps such as those in Zimbabwe in that refugees are allocated land to 
build their houses and engage in livelihoods. While these settlements also have some restrictions, they are better than camps because they give refugees a sense of security and self-reliance. Several writers and international organizations have welcomed this policy because it allows refugee families to attain socioeconomic security and reduce their dependence on housing and food aid (Omata \& Kaplan, 2013; UNHCR, 2015). Research conducted in 2013 under the auspices of the Oxford Humanitarian Innovation Project (2015) indicated that only $1 \%$ of refugees in Uganda depended completely on aid compared with over $75 \%$ of refugees in Zimbabwe. The 2016 UN Summit for Refugees declared the Ugandan policy a model for refugee integration, and UNHCR (2015) described Uganda as the most conducive environment in the world for refugees. Even Pope Francis, on his arrival in Uganda in 2015, applauded the country for demonstrating "outstanding concern for welcoming refugees, enabling them to rebuild their lives" (Ibanez, 2015). Uganda's integration practices generally fit well in Jacobsen's (2001) conceptualization of integration, which includes.

... lack of physical danger; freedom to return to the home country; access to sustainable livelihoods; access to government services like education, health, and housing; social inclusion through intermarriage and social interactions with the host community; and comparable standards of living in comparison with the host community. (p. 4)

Uganda strongly recognizes freedom of movement as key to integrating refugees, and therefore, Sect. 30 of the 2006 Refugee Act mentions it specifically. Refugees who live outside settlements (self-settled refugees) may move freely within the country. Unfortunately, though, those in settlements are restricted under the Refugee Regulations 2010, Sect. 47, which stipulates that.

The freedom of movement of a recognized refugee in Uganda is subject to reasonable restrictions specified in the laws of Uganda, or directions issued by the Commissioner, which apply to aliens generally in the same circumstances, especially on grounds of national security, public order, public health, public morals or the protection of rights and freedoms of others.

Because this right is not absolute, it violates Uganda's Constitution and the 2006 Refugee Act, especially when such restrictive regulations are religiously administered in refugee settlements. As extrapolated by Bernstein and Okello (2007), restricting freedom of movement undermines integration by making other necessary components more difficult. For example, permission is often refused refugees who apply to move to trade with local communities or search for skilled jobs. In such circumstances, refugees cannot easily develop their businesses or find employment.
From a legal perspective, Hovil (2002) stated that restricting refugees from movement obstructs their right to effective remedy. In this case, refugees also cannot travel to courts or relevant offices to submit an appeal against a court or other official decision. Indicating such a reason for travel could be tantamount to inviting denial from the settlement commandant, especially if the appeal challenges the decision of the refugee authorities. This could be even worse for prospective travelers who have no attorney to argue for them. With continuing advances in information and communication technologies, however, such restrictions on movement may now be obsolete.

Uganda's self-settled refugee population has been recorded at 78,501 (UNHCR, 2020c). Analysts have attributed this phenomenon to the conditions and restrictions associated with settlement life, and the better educational services, security, and opportunities to work and start businesses outside of the settlements (Hovil, 2007; Kaiser, 2005). Although refugee self-settlement is lawful and a steppingstone in the integration process, it has challenges of its own. For example, Hovil (2007) argues that self-settled refugees are not recognized because the government policy is more concerned with, and provides assistance and protection only to, settlement refugees. This means that the self-settled have no specific rights to protection from the government or the UNHCR, often live in terrible conditions, and are susceptible to prejudice. Self-settled refugees are also challenged in accessing health, shelter, and educational services because host communities believe that refugees must reside in designated settlements. Also worrisome is the government's lack of investment in interventions critical to reducing conflict between refugees and host communities. Several government programs that aim to balance assistance to refugees and to host communities remain on paper. For example, a policy to award $30 \%$ of external humanitarian relief to the host communities has never materialized. This lack of sharing could cause or exacerbate conflicts and endanger the rights of refugees.

From an educational perspective, Ugandan governments did partner with the European Union to establish vocational training centers in the refugee settlements. These centers equip refugees with practical skills in bakery, tailoring, carpentry and joinery, building, and metal fabrication to allow them to become competitive in the job market (Hovil, 2007). There are four vocational training centers for refugees, the largest in Nyumanzi. However, these do not go far in solving the refugee's predicament. While attaining these skills should be a huge step toward self-reliance and integration, refugees outside of settlements are hindered by high unemployment and job scarcity, employer uncertainty over the legality of employing refugees, and xenophobia (Ssemugenyi, 2011). This echoes an earlier observation that many refugees have employable skills but cannot seek work 
because they lack identity documents, are restricted to settlement areas, and face other challenges (Bernstein \& Okello, 2007). It is also clear that while some refugees have practical skills and the potential to sell their labor, most speak Arabic, Eritrean, French, Somali, or other languages but neither English nor Ugandan languages. The Ugandan government has adopted plans to address the language barriers among refugee schoolchildren through programs to build their skills in English, literacy, and mathematics (Trudell et al., 2019), but this is a long-term solution to an immediate problem.

Refugees also have a different relationship with the courts than nationals. Juvenile offenders have received particular attention (Wang et al., 2015), and although juvenile prisons and trained staff are few, juvenile cases and those of sexual and gender-based violence are addressed promptly by fulltime lawyers employed by agencies such as the UNHCR and the International Committee of the Red Cross Uganda Chapter.

\section{Challenges of Refugee Integration}

Despite several efforts in both Uganda and Zimbabwe, a host of challenges, most notably the countries' socioeconomic crises, continue to hinder effective refugee integration. Refugees are not a high priority for these states during this crisis, and state funding for their support and access to social services and economic opportunities has been greatly reduced. Briefly, since the early 1990s, Zimbabwe has suffered protracted political and socioeconomic challenges such as high unemployment, economic recessions, hyperinflation, and unabated corruption (Coltart, 2008; Dudzai et al., 2020). Dekker (2009) observes, "in the past decade a political and economic crisis has unfolded in Zimbabwe, resulting in twodigit negative growth rates, sky-rocketing inflation, decline in the rule of law and a disintegration of markets, notably, output and labor markets" (p. 1). It all started in 1990, when the government, on the advice of the International Monetary Fund and World Bank, adopted the Economic Structural Adjustment Programme (ESAP) to address spiraling public debt, liberalize the economy, and stimulate economic growth (Muchacha et al., 2016). The ESAP, which ran from 1990 to 1996, was a dismal failure that led to economic recession and high unemployment. Since then, for reasons including bad governance, corruption, and retrogressive economic policies, the Zimbabwean economy has been in freefall. In 2008, for example, Zimbabwe had the highest inflation rate in the world: over 50,000\% (Coltart, 2008), and in 2016, Muchacha et al. (2016) estimated it had over $90 \%$ unemployment and more than half its 14 million people living in abject poverty.

That socioeconomic situation has made integrating refugees in Zimbabwe extremely challenging. Due to limited funding and lack of resources, the Zimbabwean government has mainly left the care, integration, and protection of refuges to international organizations operating in refugee camps such as the UNHCR. The only functional refugee camp in Zimbabwe now is Tongogara Refugee Camp (Mhlanga \& Zengeya, 2016), supplied mainly by the World Health Organization and the UNHCR, who also have limited resources. With no support from the state, the services provided by these non-governmental organizations are inadequate and contribute to an ongoing humanitarian crisis. Results of a (2015) UNHCR/World Food Programme survey in the Tongogara camp showed that over $75 \%$ of refugees had insufficient food, over 1000 households needed housing, and new arrivals were housed by their relatives, leading to congestion and overcrowding (UNHCR, 2015). Over 75\% relied on supplies from non-governmental organizations and had no other resources. Other challenges included limited access to health care, water and sanitation, nutrition, education, and amenities (Taruvinga et al., 2021).

In Uganda, allocating land to refugees to promote their development and self-sufficiency appears a perfect model for integration, but is undermined by the scarcity and poor quality of the land (Hovil, 2002). The resulting deteriorating relationship between refugees and host communities leads to xenophobia, animosity, and finally, violent confrontation (Bagenda et al., 2003). This hostile relationship is an obstacle to integration and illustrates the large gap between the reality and the ideal of socioeconomic development for and through refugees (Koser, 2010). The refugee settlements were established in 1969 in sparsely populated zones on land never before cultivated. However, private land acquisition and the unprecedented population growth to nearly 46 million people have made land scarce (UN, 2020). Settlement boundaries are now disputed by local communities, refugees, and some government officials, each group accusing the other of encroachment and damaging interactions between the parties. Some communities have called on government to speed up the return of refugees to countries such as Rwanda that have attained some level of peace.

Although some refugees grow crops for food and to sell for extra income, sales are greatly impeded by their restricted movements (Omata \& Kaplan, 2013), and the bureaucratic difficulties involved in obtaining movement permits in both countries make the sale of agricultural products cumbersome and minimally profitable. Betts et al. (2014) explain that restricting refugees' access to markets denies their integration. Refugees who cannot travel to where prices are competitive must sell their products for whatever people are willing to pay. Transporting agricultural produce to the market, however, is greatly slowed by dilapidated roads and poor road networks, which affect local citizens as well. Tongogara Refugee Camp is about $420 \mathrm{~km}$ from Harare, Zimbabwe's political and commercial capital (Muyambo, 2018). Travel from Chipinge to Harare is normally by bus 
and often complicated by the poor condition of the road to Birchenough Bridge near Mutema and Manesa villages. The long slow trip means that refugees taking produce to Harare's competitive market may lose goods such as tomatoes to spoilage. This may limit refugees and locals alike to selling locally, and faced with stiff competition from larger suppliers, they may be forced to sell their goods at giveaway prices.

Unfortunately, the much-heralded local settlement policy has led to land scarcity, triggering disputes over land and other resources such as firewood and water. This policy has continued to demand additional chunks of land at the expense of the expanding local population. Local people therefore see the policy as depriving them of their own land and opportunity for economic emancipation (Bagenda et al., 2003), straining the gregarious and amiable relationship once enjoyed by the host and refugee communities. With an emphasis on private land acquisition, a cash economy, and food and energy crises spurring international companies to look for land to farm and mine, land in Uganda has become such a competitive resource that poor Ugandan citizens unable to cope have themselves been forced to migrate to settlements in search of land to graze their animals (Bagenda et al. (2003). Conforming to research by Ahimbisibwe (2013), who established that some sections of host communities in southwestern Uganda had permanently migrated to the Nakivale refugee settlement in search of grazing land, this situation begets more land conflicts, with each party accusing the other of encroachment. Unfortunately, these tensions not only damage interactions between refugees and host communities, but also threaten children's education as refugees fear sending their children to schools.

Language barriers remain a great obstacle to refugee integration. Uganda, for example, has over 56 native languages, most of which refugees neither speak nor understand. This has a large detrimental effect on integrating refugees into different host communities; the most vulnerable refugees are those who have not attained some minimum level of education and competency in a local language (Kaiser, 2005).

\section{Recommendations for Refugee Integration in Uganda and Zimbabwe}

As the number of refugees increase, Uganda and Zimbabwe need to undertake concerted efforts to meaningfully integrate refugees within their borders. Critical to refugee integration is the refugee host-community relationship, a fulcrum upon which integration must balance. Social workers and the governments of Uganda and Zimbabwe should work toward constructing positive relationships among refugees, host communities, and government services and authorities. For example, these countries could adopt and develop interventions that benefit both refugees and host communities, such as the $30 \%$ humanitarian assistance promised by the Ugandan Prime Minister's Office to host communities. We also recommend that both countries promote programs such as regular meetings or community events to bring refugee and host communities together, encourage social harmony and mitigate conflicts. Open discussions on shared resources, areas that have been major sources of conflict between refugees and host communities in Uganda such as roads, sources of water, health facilities, education facilities, and environmental reserves, should also be intensified.

Equally important, the encampment and local settlement policies in Zimbabwe and Uganda, respectively, affect the full integration of refugees in several ways. These policies of confining refugees to certain areas prevent them from integrating into local society, allow their continuing characterization as foreign "others," and contravene Article 26 of the 1951 Convention Relating to the Status of Refugees and Article 12 of the International Covenant on Civil and Political Rights, which provide refugees with the same human rights as locals (Bagenda et al., 2003). By providing land for agricultural livelihoods, Uganda is making significant progress toward the economic integration of refugees. Zimbabwe and many other countries need to learn from Uganda and implement similar policies to provide refugees with livelihoods and the opportunity to produce their own food and reduce their dependence on food aid. To address the problem of scarcity of resources, countries should empower refugees by providing them with socioeconomic tools such as micro-credit to help them create and support their own livelihoods, through work or through small and medium enterprises.

The social workers and governments of Uganda and Zimbabwe need to raise mutual awareness between refugees and host communities, to encourage positive relationships, and to expand those relationships to include the government services and authorities responsible for integration. More importantly, governments and social workers need to publicize the rights and obligations of refugees to host communities who may need to (re)learn to extend genuine kindness and warmth to refugees.

While we appreciate the Ugandan settlement policy, Uganda's refugee services need to be decentralized to the refugee host districts. This will increase government spending on social services in refugee-hosting districts to facilitate refugee integration. Moreover, it will not only promote equitable resource distribution based on need, but also promote a culture of ownership and sustained peaceful coexistence between refugees and host communities. Decentralizing refugee services will also encourage districts to integrate refugee activities and projects in their developmental planning and budgeting. All key actors on refugee issues including local governments, the UNHCR, the Office of the Prime Minister, and non-governmental organizations need to share their activities and approaches and identify critical gaps in 
refugee integration. Besides reducing duplication, such inter-agency cooperation will help to capture all partner support in district development plans in a database for better planning refugee services. It will also promote partnerships between refugee host districts and other organizations and identify critical issues for discussion in the district councils.

Another critical problem in refugee integration in Uganda is the language barrier. Providing language lessons to refugees would minimize communication barriers to social and cultural integration. Besides fixing communication barriers, humanitarian agencies and governments should promote the meaningful participation of both refugees and host populations in making decisions on matters that affect them. When both refugees and host communities feel included, especially through collaboration and a bottom-up approach, they can share ownership and work together to sustain and promote the holistic and mutually beneficial integration of the refugees. This will also make refugee integration processes more rational, increasing the trust of individual and institutional donors, whose increased donations would support successful interventions and make integration sustainable.

Zimbabwe's poor integration of refugees may be linked to its failure to inculcate in host communities the Ubuntu values and attributes upon which Zimbabwean society is ostensibly based. We recommend, therefore, consciousnessraising programs to educate host communities on the significance of Ubuntu philosophy, which is premised on the group solidarity central to the survival of African communities (Mbigi, 2005). According to Ubuntu philosophy, an African is not a rugged individual, but a person living in a community (Mbigi, 2005). In this view, refugees living in the hostile environment of settlements characterized by hunger, isolation, deprivation, and poverty rely for their very survival upon the Ubuntu spirit of community solidarity and brotherly and sisterly concern. When host communities believe and practice the values of Ubuntu, community members will be motivated to participate in benevolent initiatives based on respect, dignity, caring, and sharing (Fraser-Moleketi, 2007). Social workers from the Department of Social Development and Social Workers working at Tongogara Refugee Camp might promote the spirit of Ubuntu when encouraging communities to care and share with refugees, by encouraging community members, for example, to give refugees parttime jobs such as planting fields in the rainy season, weeding fields, herding cattle and goats, and harvesting crops. These jobs would help to establish networking and interdependency between host communities and refugees, which in turn could establish the spirit of togetherness cherished in Ubuntu philosophy. In more practical terms, this would also provide refugees with a livelihood and access to food, money, and clothing.

The Ubuntu spirit could also be fostered in local companies who might be encouraged to demonstrate social responsibility by donating some of their profits to refugee communities. Social links created between refugees and such companies, both multi-national and local, would help establish and foster institutional and community cultures of respect, dignity, caring, and sharing with refugee communities. Even minor steps in this direction could be great strides toward refugees' integration as they begin to feel accepted in the host country. Social workers in Zimbabwe and other host countries have to lobby and advocate to bring about such programs (Mhlanga \& Zengeya, 2016) to enhance not only refugees' integration, but also their well-being. With the small or dangerous chances most refugees have of returning home, social workers must lobby governments and other relevant actors and advocate for policies and programs to integrate refugees in their countries of asylum.

\section{Conclusion}

The world is becoming increasingly globalized, and the movement of goods, capital, ideas, and culture beyond borders is unlikely to change; rather, it will increase as globalization is irreversible. This essay demonstrates the complexity of-and the major impact of scant resources on-integrating refugees in Zimbabwe and Uganda. Refugees are restricted by both lack of resources and restraints on their movements, meaning they do not have the same rights as locals. We argue that successful integration in Zimbabwe and Uganda depends on refugees' freedom of movement, and we implore these and other countries to utilize advances in information, communications, and technology to manage and protect refugees in transit rather than restrict their movements. To achieve refugee integration, both Zimbabwean and Ugandan governments should provide and encourage language support, micro-credit facilities, and programs to facilitate social harmony and mitigate conflicts. Government policy must also balance assistance to refugees with the needs and values of the host communities. A policy to award $30 \%$ of external humanitarian relief to host communities should urgently be implemented to avoid conflicts between host communities and refugees. To facilitate local ownership of refugee programs, we encourage Ugandan and other governments to decentralize refugee services and integrate them in local development plans. Finally, activities that promote talent building and community engagement in events such as cultural galas, sports activities, and community dialogue geared toward harmonious living should be facilitated. Such measures, especially dialogues, will not only help to identify violent hotspots, but will equally reconcile those who had been aggrieved by either party.

More significantly, refugee integration could bring new opportunities to both Zimbabwe and Uganda. As the World Bank (2011) alluded, such integration can promote economic 
expansion and innovation, and hence breathe new life and dynamism into a regional economy. This suggests that were refugees given adequate room to express their skills and expertise through various economic activities, they could initiate new models of production within the local economy while contributing significantly to the nation's gross domestic product. Arguably, effective integration would allow and encourage refugees to engage in a variety of entrepreneurial activities that would increase the supply of goods and services. This would not only stimulate market growth, but also expand trade between locals and refugees, thus strengthening integration and furthering growth.

Funding Open access funding provided by Örebro University.

Open Access This article is licensed under a Creative Commons Attribution 4.0 International License, which permits use, sharing, adaptation, distribution and reproduction in any medium or format, as long as you give appropriate credit to the original author(s) and the source, provide a link to the Creative Commons licence, and indicate if changes were made. The images or other third party material in this article are included in the article's Creative Commons licence, unless indicated otherwise in a credit line to the material. If material is not included in the article's Creative Commons licence and your intended use is not permitted by statutory regulation or exceeds the permitted use, you will need to obtain permission directly from the copyright holder. To view a copy of this licence, visit http://creativecommons.org/licenses/by/4.0/.

\section{References}

Ahimbisibwe, F. (2013). The effect of land conflicts on the livelihoods of refugees: Implications for refugee protection in Uganda. Research Journal of Social Science and Management, 3. https:// www.theinternationaljournal.org/ojs/index.php?journal=tij\& page $=$ article \&op $=$ view \&path $\% 5 \mathrm{~B} \% 5 \mathrm{D}=2215$

Albrow, M. (1990). Introduction. In M. Albrow \& E. King (Eds.), Globalization, knowledge and society: Readings from international sociology. London: Sage.

Angell, N. (1911). The great illusion: A study of the relation of military power in nations to their economic and social advantage. G. P. Putnam's Sons.

Appadurai, A. (1990). Disjuncture and difference in the global cultural economy. In M. Featherstone (Ed.), Global culture: Nationalism, globalization and modernity (p. 90). Sage.

Bagenda, E., Naggaga, A., \& Smith, E. (2003). Land problems in Nakivale refugee settlement and implications for refugee protection in Uganda. Refugee Law Project Working Paper No.8. Kampala: Makerere University.

Bauman, Z. (1998). Globalization: The human consequences. Polity Press.

Beck, U. (2000). The cosmopolitan perspective: Sociology of the second age of modernity. British Journal of Sociology, 51(1), $79-105$.

Beerkens, H. J. J. G. (2004). Global opportunities and institutional embeddedness: Higher education consortia in Europe and Southeast Asia. University of Twente Center for Higher Education Policy Studies.

Bernstein, J., \& Okello, M. C. (2007). To be or not to be: Urban refugees in Kampala. Refuge, 24(1), 46-56.
Betts, A., Bloom, L., Kaplan, J. \& Omata, N. (2014). Refugee Economies: Rethinking Popular Assumptions. University of Oxford, UK. https://www.rsc.ox.ac.uk/files/files-1/refugee-economies2014.pdf

Cambridge, J. (2000). International schools, globalisation and the seven cultures of capitalism. In M. C. Hayden \& J. J. Thompson (Eds.), International schools and international education (pp. 179-190). Kogan Page.

Castles, S. (2004). Why migration policies fail. Ethnic and Racial Studies, 27(2), 205-227.

Castles, S., Maja, K., Ellie, V., \& Steven V. (2002). Integration: Mapping the field. Oxford: Centre on Migration, Policy, and Society and Refugee Studies Centre. http://www.blink.org.uk/docs/mapping_the_ field.pdf

Castles, S., \& Miller, M. J. (2003). The age of migration: International population movements in the modern world. The Guilford Press.

Castles, S., \& Van Hear, N. (2005). Developing DFID's policy approach to refugees and internally displaced persons: Report to the Conflict and Humanitarian Affairs Department. Refugee Studies Centre.

Chigwedere, S. A. (1998). The roots of the Bantu. Mutapa Publishing House.

Chikanda, A., \& Crush, J. (2016). The geography of refugee flows to Zimbabwe. African Geographical Review, 35(1), 18-34.

Coltart, D. (2008). A decade of suffering in Zimbabwe. The Cato Institute. https://object.cato.org/sites/cato.org/files/pubs/pdf/ dpa5.pdf

Crisp, J. (2004). The local integration and local settlement of refugees: A conceptual and historical analysis, Working Paper No. 102, New Issues in Refugee Research. United Nations High Commissioner for Refugees. https://www.unhcr.org/ enus/research/working/407d3b762/local-integration-localsettlement-refugees-conceptual-historical-analysis.html

Dekker, M. (2009). Livelihoods and economic crisis: The case of smallholder farmers in Zimbabwe (1999-2008). In Economic development in Africa. Oxford UK: Centre for the Study of African Economies, University of Oxford.

Dudzai, C., Wamara, K. C., \& Mhlanga, C. (2020). The vices of corruption within the Informal Sector: Lessons learnt from vendors vending at Gulf Complex in Harare's Central Business District. Journal of Public Administration and Development, 5(1), 31-40.

Fraser-Moleketi, G. (2007). Towards a common understanding of corruption in Africa. Public Policy and Administration, 2(2), 239-249.

Fukuyama, F. (1992). The end of history and the last man. Free Press.

Giddens, A. (1990). The Consequences of Modernity. Cambridge: Polity/Blackwell.

Giddens, A. (2001). Sociology. Polity Press.

Harvey, D. (2005). A brief history of neoliberalism. Oxford University Press.

Held, D., MacGrew, A., Goldblatt, D., \& Perraton, J. (1999). Global transformations: Politics, economics and culture (pp. 1-31). Stanford University Press.

Held, D., McGrew, A., Goldblatt, D., \& Perraton, J. (2000). Global transformations: politics, economics and culture. In C. Pierson \& S. Tormey (Eds.), Politics at the edge. Political studies association yearbook series. London: Palgrave Macmillan.

Hovil, L. (2002). Free to stay, free to go? Movement, seclusion and integration of refugees in Moyo District. Working Paper No. 4. Office for the Coordination of Humanitarian Affairs Relief Web. https://reliefweb.int/report/uganda/refugee-law-project-workingpaper-no-4-free-stay-free-go-movement-seclusion-and

Hovil, L. (2007). Self-settled refugees in Uganda: An alternative approach to displacement? Journal of Refugee Studies, 20(4), 599-620. 
Hugman, R., Moosa-mitha, M., \& Moyo, O. (2010). Towards a borderless social work: Reconsidering notions of international social work. International Social Work, 53(5), 629-643.

Ibanez, D. (2015). Pope praises Ugandans for helping refugees rebuild their lives. http://www.catholicnewsagency.com/news/popepraises-ugandans-for-helpingrefugees-rebuild-their-lives-37848/

Jacobsen, K. (2001). The forgotten solution: Local integration for refugees in developing countries. Working Paper No. 45, New Issues in Refugee Research. UNHCR. https://www.unhcr.org/research/ working/3b7d24059/forgotten-solution-local-integrationrefugeesdeveloping-countries-karen.html

Jones, A. (2006). Dictionary of globalization. Polity Press.

Kaiser, T. (2005). Participating in development? Refugee protection, politics and developmental approaches to refugee management in Uganda. Third World Quarterly, 26(2), 351-361.

Karakayali, S., \& Rigo, E. (2010). Mapping the European space of circulation. Duke University Press.

Klaaren, J., \& Rutinwa, B. (2004). Towards the harmonisation of immigration and refugee law in SADC. Idasa/Queen's University.

Koser, K. (2010). Dimensions and dynamics of irregular migration. Population Space and Place, 16, 181-193.

Kreibaum, M. (2016). Their suffering, our burden? How Congolese refugees affect the Ugandan population. World Development, $78(1), 262-287$.

Lomo, Z., Naggaga, A., \& Hovil, L. (2001). The phenomenon of forced migration in Uganda: An overview of policy and practice in an historical context. Makerere University.

Mbigi, L. (2005). The spirit of African leadership. Knowles Publishing.

Mhlanga, J., \& Zengeya, R. M. (2016). Social work with refugees in Zimbabwe. African Journal of Social Work, 6(1).

Mittelman, J. H. (2004). Whither globalization? The vortex of knowledge and ideology. Routledge.

Muchacha, M., Dziro, C., \& Mthetwa, E. (2016). The implications of neoliberalism for the care of orphans in Zimbabwe: Challenges and opportunities for social work practice. Aotearoa New Zealand Social Work, 28(2), 84-93.

Muyambo, T. (2018). Indigenous knowledge systems of the Ndau people of Manicaland province in Zimbabwe: A case study of Bota Reshupa. [Doctoral thesis]. University of Kwazulu-Natal.

Office of the Prime Minister. (2017). Uganda Solidarity Summit \#17 on Refugees. Translating New York Declaration commitments into action. Requirements for a comprehensive refugee response in Uganda. https://reliefweb.int/sites/reliefweb.int/files/resources/ UgandaComprehensiveRefugeeResponsel_20_June_2017.pdf

Omata, N., \& Kaplan, J. (2013). Refugee livelihoods in Kampala, Nakivale and Kyangwali refugee settlements: Patterns of engagement with the private sector. University of Oxford.

Oxford Humanitarian Innovation Project. (2015). Refugee economies in Uganda: Challenging popular myths about refugees. Oxford: Centre for Refugee Studies. https://www.rsc.ox.ac.uk/policy/ refugee-economies-in-uganda

Penninx, R. (2004). Integration of migrants: economic, social, cultural and political dimensions. Background paper for the UNECE conference 12-14 January 2004, European Population Forum, Geneva. https://www.international.metropolis.net

Polzer, T. (2008). Invisible integration: How bureaucratic, academic and social categories obscure integrated refugees. Journal of Refugee Studies, 21(4), 476-497.

Refugee Law Project. (2009). Critique of the Refugees Act (2006). Makerere University.

Republic of Zimbabwe. (2001). Chapter 4:03: Refugees Act. Harare, Zimbabwe.
Robinson, V. (1998). Defining and measuring successful refugee integration. In Proceedings of ECRE International Conference on Integration of Refugees in Europe, Antwerp November 1998. European Council on Refugees and Exiles.

Sharpe, M., \& Namusobya, S. (2012). Refugee status determination and the rights of recognized refugees under Uganda's Refugees Act 2006. International Journal of Refugee Law, 24(3), 561-578.

Sigona, N. (2005). Refugee integration: Policy and practice in the European Nation, Refugee Survey Quarterly, 24(4).

Ssemugenyi, D. (2011). Challenges to refugees' freedom of movement in Uganda: A case of self-settled refugees in Kisenyi, Kampala. [Thesis]. https://www.semanticscholar.org/paper/Challenges-toRefugees\%27-Freedom-of-Movement-in-A-of-Ssemugenyi/76bb6 ce635d4f5737235c0a43318ca48f78a68d3

Stake, R. E. (1995). The art of case study research. Sage.

Taruvinga, R., Hölscher, D., \& Lombard, A. (2021). A critical ethics of care perspective on refugee income generation: Towards sustainable policy and practice in Zimbabwe's Tongogara Camp. Ethics and Social Welfare, 5(1), 36-51.

Trudell, B., Nannyombi, P., Teera, L., \& Africa, S. I. L. (2019). A bridging programme for refugee children in Uganda: Perspectives and recommendations. https://resourcecentre.savethechildren.net/libra ry/bridging-programme-refugee-childrenuganda-perspectives-andrecommendations

UN. (2015). International migration report. UN Department of Economic and Social Affairs.

UN (2020). UNDESA World Social Report 2020: Inequality in a rapidly changing world. https://www.un.org/development/desa/dspd/ world-social-report/2020-2.html

UNHCR. (2014). Global report. http://www.unhcr.org/gr14/index.xml

UNHCR. (2015). People of concern. http://reporting.unhcr.org/node/ 5129

UNHCR. (2018). Uganda country refugee response plan: The integrated response plan for refugees from South Sudan and the Democratic Republic of Congo. https://data2.unhcr.org/en/documents/ download/63273

UNHCR. (2020a). World migration report 2020. United Nations. https://www.un.org/sites/un2.un.org/files/wmr_2020.pdf

UNHCR. (2020b). Zimbabwe-Global focus. https://reporting.unher. prg/zimbabwe

UNHCR. (2020c). Uganda Comprehensive Refugee Response Portal. https://www.ugandarefugees.org/en/country/uga

United Nations. (2000). Institutional response to globalization. Report prepared by the Secretariat for the Group of Experts on the United Nations Programme in Public Administration and Finance at its Fifteenth Meeting, ST/SG/AC.6/L.6. UN.

United Nations, UN. (1951). Convention Relating to the Status of Refugees. United Nations.

United Nations High Commissioner for Refugees, UNHCR. (2003). Refugees in Uganda move towards self-reliance. Uganda: UNHCR. http://www.unhcr.org/3f8aa81e4.html

Wang, J. S. H., Ssewamala, F. M., \& Han, C.-K. (2015). Family economic strengthening and mental health functioning of caregivers for AIDS-affected children in rural Uganda. HHS Public Access, 33(4), 395-401.

World Bank. (2011). Volume II: Study on impacts and costs of forced displacement: State of the art literature review. The World Bank.

Publisher's Note Springer Nature remains neutral with regard to jurisdictional claims in published maps and institutional affiliations. 